\title{
CLONING, EXPRESSION AND PURIFICATION OF HUMAN TRUNCATED SIRT1
}

\section{RAHUL KUMAR\#, ABHAY KUMAR SINGH\#, ROSHAN PANDEY AND SHARMISTHA DEY*}

Department of Biophysics, All India Institute of Medical Sciences, New Delhi, India.

*Corresponding Author: Email- drsharmistha@gmail.com

Received: May 04, 2012; Accepted: May 17, 2012

\begin{abstract}
Sirtuins belong to an evolutionarily conserved class of proteins that regulate a variety of cellular functions such as genome maintenance, longevity, and metabolism. The conserved part of amino acids residues 244-498 of full length human SIRT1 have the functional activity. To construct a functional form of SIRT1 by DNA recombinant technology, we have expressed and purified truncated protein of 420 (193 to 611) amino acids of MW $47 \mathrm{kDa}$ in prokaryotic system, Ecoli BL21 (DE3) strain. This functional protein has a potential to be used as a diagnostic tool and for the development of new therapeutic agent for age related disease.
\end{abstract}

Key words- Truncated SIRT1; Protein expression; Mass Spectroscopy; Western blot.

Citation: Rahul Kumar, et al. (2012) Cloning, expression and purification of human truncated SIRT1. International Journal of Molecular Biology, ISSN: 0976-0482 \& E-ISSN: 0976-0490, Volume 3, Issue 2, pp.-49-54.

Copyright: Copyright@2012 Rahul Kumar, et al. This is an open-access article distributed under the terms of the Creative Commons Attribution License, which permits unrestricted use, distribution, and reproduction in any medium, provided the original author and source are credited.

\section{\# - Authors Contributed equally}

\section{Introduction}

Sirtuin or silence information regulator comprises an universal conserved family of $\mathrm{NAD}^{+}$(Nicotinamide adenine dinucleotide) dependent deacetylases conserved from bacteria to human and play a role in a wide variety of important biological processes including development, heterochromatin formation, transcriptional silencing, DNA recombination and repair, genomic stability, apoptosis, axonal protection, fat metabolism, metabolic regulation and longevity $[1,2]$. This enzyme was first isolated from yeast, and later it was found to be present in mammals including humans. There are seven human sirtuins (1-7) that display diversity in cellular localization and function. They contain a conserved catalytic core domain comprising of approximately 275 amino acids. SIRT1 is most studied among the 7 sirtuin family member, is highly expressed in several adult tissue such as brain, heart and skeletal muscle [3]. Calorie restriction, the only known mechanism which has been reported to delay ageing is mediated by sirtuin gene family which were shown to have anti ageing function in yeast [4] Caenorhabtidis [5], Drosophila [6] and mammals including rodents [7], and perhaps primates [8, 9]. SIRT1 is localized in the nucleus $[10,11]$ and cytoplasm [12]. It interacts and deacetylates many proteins like p53 [10, 11], the forkhead transcription factor
FOXO3A [13], BCL6 [14], TAF68 [15], HES1 [16] and CTIP2 [17]. It is an important mediator of longevity through induction of cell cycle arrest and resistance to oxidative stress by deacetylating FOXO3. Sirtuins have emerged as a therapeutic target to treat age related diseases. SIRT1 controls insulin secretion from pancreatic beta cells via UCP2, FOXO1 and NAD metabolism and can help on the development of new therapeutic tool for insulin resistance and type2 diabetes [18]. It promotes fatty acid mobilization in white adipose tissues by deacetylating and repressing PPARy (Peroxisome proliferator activated receptor y) [19]. In skeletal muscles, it results in increased aerobic capacity $[20,21]$ while in liver it increases gluconeogenisis [22] by deacetylating and activating PGC1a (PPAR1y coactivator 1a). Three different mRNA sequence of human SIRT1 are known from Gene bank NM_012238 (4110 bp), NM_001142498.1 (3604bp) and BC012499.1 (3691 bp) respectively, with their respective frames encoding 747, 452 and 555 amino acids residues. The preliminary crystal structure of truncated SIRT1 from 140-747 amino acid residues is also reported [23]. In the present study, we report the cloning, expression and purification of truncated human sirtuin constructed from 193-611 amino acid residues. 


\section{Materials and methods}

Bio-informatics Analysis

mRNA sequence of human SIRT1 gene was obtained from NCBI Gen Bank (www.ncbi.nlm.nih.gov/genbank/) under accession No. NM_012238. NCBI ORF finder (www.ncbi.nlm.nih.gov/projects/ gorf/) was used to find out the ORF and respective amino acid sequence. The deduced amino acids sequence was analyzed by Expasy MW/pl (web.expasy.org/compute_pi/) to calculate the molecular weight and pl of the protein. Homologues were explored by BLAST programme (blast.ncbi.nlm.nih.gov/Blast.cgi) in NCBI Gen Bank database and multiple sequence alignment was performed using Clustal W programme. (www.ebi.ac.uk/Tools/msa/ clustalw2/).

\section{Cloning \\ PCR}

Truncated SIRT1 gene was amplified by using Pfu Taq Polymerase (Phusion). The forward and reverse primers used for the amplification were CGGGATCATGATTGGCACAGATCC and CCGCTCGAGCTATTCATTTTTCTCCCC respectively having BamH1 and Xho1 sites.

Cloning into $p G E M T$ easy vector

The amplified product was purified using PCR cleanup kit (Promega) and adenylated by Taq polymerase followed by cloning into pGEMT easy vector (Promega). The ligation mixture was transformed into E.coli DH5a competent cells and positive clones were identified by blue white screening. The sequence of positive clones was confirmed by PCR-based sequencer.

\section{Sub-cloning into expression vector}

Plasmid was extracted from the positive clones by using Plasmid Purification Kit (Promega). Directional cloning was performed by using BamH1 and Xho1 as a restriction sites to clone truncated SIRT1 gene into pET28a+vector using T4DNA ligase. Ligation mixture was then transformed into expression host E.coli BL21 (DE3) competent cells.

\section{Expression}

E.coli BL21 cells possessing recombinant plasmid were allowed to grow in $100 \mathrm{ml}$ of LB media containing Kanamycin $(50 \mathrm{mg} / \mathrm{L})$ at $370 \mathrm{C}$ until absorbance at $600 \mathrm{~nm}$ reached 0.6 and then induced with $1 \mathrm{mM}$ IPTG(Isopropyl $\beta$-D-1-thiogalactopyranoside). The cells were harvested after $5 \mathrm{hrs}$ of induction and weighed. The induced and uninduced cultures were analysed by SDS- PAGE to ensure the recombinant protein expression.

\section{Protein purification and on column refolding}

Inclusion bodies obtained after sonication of the 0.3 grams of harvested cells in $1.2 \mathrm{ml}$ of $50 \mathrm{mM}$ Tris- $\mathrm{HCl}$ were re-suspended in Buffer A (100 mM sodium phosphate $\mathrm{pH} 8.0$, Tris- $\mathrm{HCl} \mathrm{pH} 8.0$ and $8 \mathrm{M}$ urea), centrifuged and the supernatant was loaded on $1 \mathrm{ml}$ of Ni-NTA resin (Qiagen) pre equilibrated with Buffer $A$. The column was successively washed with Buffer B (100 mM sodium phosphate $\mathrm{pH} 8.0$, Tris- $\mathrm{HCl} \mathrm{pH} 8.0,8 \mathrm{M}$ urea and $20 \mathrm{mM}$ imidazole), Buffer $\mathrm{C}(100 \mathrm{mM}$ sodium phosphate $\mathrm{pH} 8.0$, Tris- $\mathrm{HCl} \mathrm{pH} 8.0$ and $20 \mathrm{mM}$ imidazole), Buffer D (100 mM sodium phosphate $\mathrm{pH} 8.0$, Tris- $\mathrm{HCl} \mathrm{pH} \mathrm{8.0,20} \mathrm{mM} \mathrm{imidazole} \mathrm{and} \mathrm{10 \%} \mathrm{glycerol)} \mathrm{and} \mathrm{Buffer} \mathrm{E}$ (100 mM sodium phosphate $\mathrm{pH} 8.0$, Tris- $\mathrm{HCl}$ pH 8.0, 20 mM imid- azole, $10 \%$ Glycerol and $300 \mathrm{mM} \mathrm{NaCl})$. Finally, the recombinant protein was eluted with Buffer $\mathrm{F}(100 \mathrm{mM}$ sodium phosphate $\mathrm{pH}$ 8.0 , Tris- $\mathrm{HCl} \mathrm{pH} \mathrm{8.0,300} \mathrm{mM} \mathrm{imidazole} \mathrm{and} 10 \%$ glycerol and 300 $\mathrm{mM} \mathrm{NaCl}$ ) in a refolded state.

\section{Characterization of truncated SIRT1 Western Blotting}

Purified protein along with human serum sample was separated by SDS PAGE and transferred onto PVDF membrane (MDI). Membrane was then blocked with 3\% Bovine Serum Albumin (Bio Basic Inc.) prepared in TBS1 $150 \mathrm{mM} \mathrm{NaCl}$ and $10 \mathrm{mM}$ Tris. $\mathrm{HCl}$ $\mathrm{pH} 7.5)$ for 2 hrs followed by overnight incubation in 1:500 rabbit antihuman SIRT1 polyclonal antibody(Enzo Life Sciences). The blot was then washed with TBS-T $(500 \mathrm{mM} \mathrm{NaCl}, 20 \mathrm{mM}$ Tris $\mathrm{HCl}$ $\mathrm{pH} 7.5$ and $0.05 \%$ Tween) 3 times for $10 \mathrm{mins}$ and incubated with 1:5000 HRP (Horse Radish Peroxidase) conjugated goat secondary antibody (Genescript). The membrane was washed as above with TBS-T and visualized using Enhanced Chemiluminescent system (Thermo Scientific).

\section{Surface Plasmon resonance}

All SPR measurements were performed at $25^{\circ} \mathrm{C}$ using the BIAcore-2000 apparatus (Pharmacia Biosensor AB, Uppsala, Sweden) which is a biosensor-based system for real time specific interaction analysis. The IgG SIRT1 of human origin (ENZO Biotechnology, CA) was immobilized on the CM5 sensor chip using the amine coupling kit (Pharmacia Biosensor AB, Sweden). The running buffer used was $10 \mathrm{mM}$ HBS-EP (10 mM HEPES pH 7.4, $150 \mathrm{mM}$ Sodium Chloride, $3 \mathrm{mM}$ EDTA, 0.005\% Polysorbate 20) containing $0.005 \%$ surfactant P20. The dextran on the chip was equilibrated with running buffer and was activated with an equal volume $(110 \mu \mathrm{l})$ of EDC (N-ethyl-N'-3 diethylaminopropyl carbodiimide) (15 mg in $200 \mu \mathrm{l}$ of water) and NHS (Nhydroxysuccinimide) $(2.3 \mathrm{mg}$ in $200 \mu \mathrm{l}$ of water) mixture. This mixture was passed at a flow rate of $5 \mu \mathrm{l} / \mathrm{min}$ for 15 mins. Then $250 \mu \mathrm{l}$ of antibody with $100 \mu \mathrm{l}$ in $10 \mathrm{mM}$ sodium acetate (pH 4.7) was injected at a flow rate of $5 \mu \mathrm{l} / \mathrm{min}$ and the unreacted groups were blocked by ethanolamine ( $\mathrm{pH} 8.5)$.

Six different concentrations of the purified human truncated SIRT1 $(0.62,3.12,6.25,18.75,31.25,62.25 \mathrm{ng})$ were passed over the immobilized SIRT1 antibody. As the analyte (pure human truncated SIRT1) binds with the immobilized anti-lgG SIRT1 (ligand) over the CM5 sensor chip, an increase in SPR signal (expressed in response units, $\mathrm{RU}$ ) was observed. The binding of the pure human truncated SIRT1was monitored by the change in RU values of the sensogram and the corresponding RUs were obtained.

\section{Mass Spectrometry Analysis}

The purified protein band was excised from the gel and then subjected to in gel reduction, alkylation and tryptic digestion. The MS/ MS was used to determine the mass and sequence of the protein. Each of the peptide was used to BLAST search to confirm that the protein identified by Mascot search programme was the only relevant match in the non redundant protein database for a particular peptide sequence and statistically significant hits were recorded together with the number of peptides and percentage coverage of the protein. 


\section{Activity assay for SIRT1}

Synthesis of Acetylated $\mathrm{N}$ terminal tail of histone $\mathrm{H} 3(\mathrm{AcH} 3)$

Acetyl lysine peptide based on the sequence of $\mathrm{N}$ terminal tail of histone $\mathrm{H} 3(\mathrm{AcH} 3)$ having sequence $\mathrm{H}_{2} \mathrm{~N}-\mathrm{KSTGGK}\left(\mathrm{COCH}_{3}\right)$ APRKQ-OH was synthesised by solid phase peptide synthesis using automated peptide synthesizer (PS3 Protein technology, USA) using Fmoc and Wang resin (G.L. Biochem, China) chemistry. The solvent used for synthesis was DMF (dimethylformamide). HBTU (2-(1H-Benzotriazole-1-yl)-1,1,3,3-tetramethyluronium hexafluorophosphate) was used as an activator of the Fmoc amino acids. Fmoc was deprotected by $20 \%$ piperidine and Wang resin was cleaved by TFA (trifluoroacetic acid). The peptides were precipitated from dry ether.

\section{Purification of Nicotinamidase}

E.coli BL21(DE3) cells harboring plasmid pPNC2 which encodes nicotinamidase protein were allowed to grow until absorbance at $600 \mathrm{~nm}$ reached 0.6 and then induced with $1 \mathrm{mM} \mathrm{IPTG}$. Harvested cells were dissolved in buffer1 $(20 \mathrm{mM}$ sodium phosphate buffer $\mathrm{pH} 7.5,500 \mathrm{mM} \mathrm{NaCl}$ and $20 \mathrm{mM}$ imidazole), sonicated and the cell free extract was loaded on Ni-NTA resin (Qiagen) pre equilibrated with buffer1, followed by washing with the same buffer and finally the protein was eluted with buffer2 $(20 \mathrm{mM}$ sodium phosphate buffer $\mathrm{pH} 7.5,500 \mathrm{mM} \mathrm{NaCl}$ and $500 \mathrm{mM}$ imidazole). [24] Enzyme coupled assay

Reaction mixture for the coupled enzymatic assay consisted of 3.3 $\mathrm{mM} \mathrm{AcH} 3,3 \mathrm{mM} \mathrm{NAD}+$, $2.4 \mathrm{mM} \mathrm{NAD}(\mathrm{P}) \mathrm{H}$ (Nicotinamide adenine dinucleotide phosphate), $13 \mathrm{mM}$ DTT (Dithiothreitol), $13.7 \mathrm{mM}$ aKG (aKetoglutarate), 2 units of GDH (Glutamate dehydrogenase) and $2 \mu \mathrm{M}$ Nicotinamidase. All assay components except SIRT1 were incubated until absorbance at $340 \mathrm{~nm}$ gets stabilized and the reaction was initialized by the addition of truncated SIRT1 protein [25].

\section{Results \\ Bioinformatics Analysis}

The sequence of a $4110 \mathrm{bp}$ mRNA of full length human SIRT1 was obtained from Gen Bank under accession no. NM_012238 which contain an ORF of 2244 bp encoding a protein of 747 amino acid residues. Since the catalytic core of full length human SIRT1 spans a region of 244-498 amino acid residues, forward and reverse primers were designed to amplify a1260 bp fragment starting 577 bp downstream of the original ORF initiation site encoding amino acid sequences from 193-612 residues (Fig1). The gene bank accession No. is JQ768366. The deduced protein was found to be $47 \mathrm{kDa}$ having a pl value of 5.1 by using Bioinformatics tool.

\section{Cloning}

Truncated SIRT1 gene was amplified using Pfu polymerase and the PCR product was found to be of $1260 \mathrm{bp}$. The purified PCR product was then cloned into pGEMT easy vector successfully and sequencing results showed that there was no nucleotide error in the truncated SIRT1 gene.

Prokaryotic expression vector $\mathrm{pET} 28 \mathrm{a}^{+}$which possesses a high stringency $\mathrm{T} 7$ promoter and an $\mathrm{N}$ - terminal His Tag has been recognized as one of the most powerful tool for producing recombinant proteins in $E$. coli. The vector also possesses a thrombin cleavage site. The truncated SIRT1 gene was directionally sub- cloned into pET28a+ and transformed into E.coli BL21(DE3) cells.

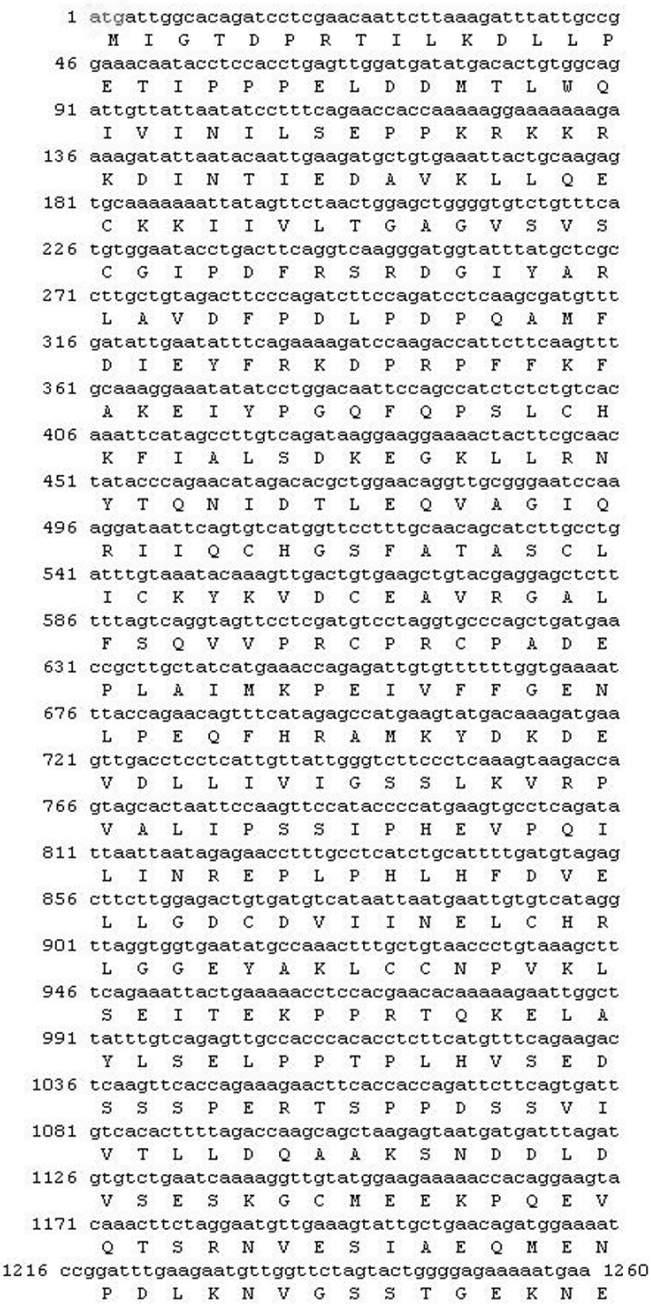

Fig. 1- The cDNA sequence and deduced 193-612 amino acid residues of human truncated SIRT1

\section{Expression and Purification}

The expression of truncated gene was induced with $1 \mathrm{mM}$ IPTG. Induced and uninduced cultures were compared by SDS PAGE and a specific band of about $51 \mathrm{kDa}$ corresponding to truncated SIRT1 protein was detected in induced culture (Fig 2).

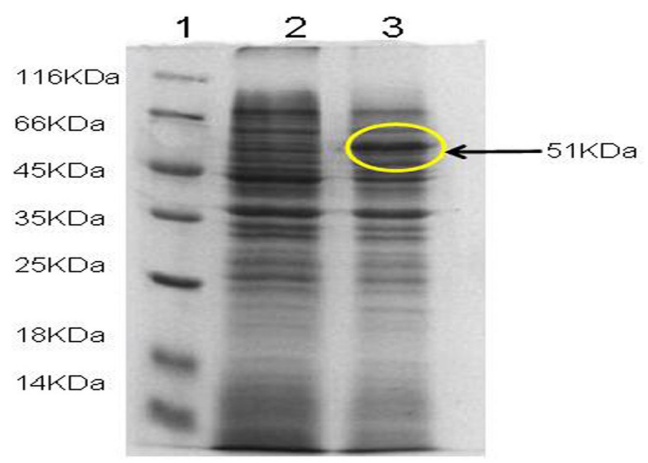

Fig. 2- Expression of human truncated SIRT1 in E. coli BL21 cells. Lane 1: molecular weight marker, Lane2 and 3: uninduced and induced cells respectively 
In order to obtain highly purified recombinant protein the inclusion bodies were solubilised in $8 \mathrm{M}$ urea and passed through Ni-NTA resin. The purity of the eluted recombinant protein was analyzed by SDS PAGE which detected a single band of about $51 \mathrm{kDa}$ (Fig 3). The protein sequence obtained of molecular weight $47 \mathrm{kDa}$ showed $51 \mathrm{kDa}$ band in SDS PAGE due to the presence of fused His tag along with extra amino acid residues provided by the vector. Recombinant truncated SIRT1 was produced in large quantities, greater than $5 \%$ of the total cell proteins.

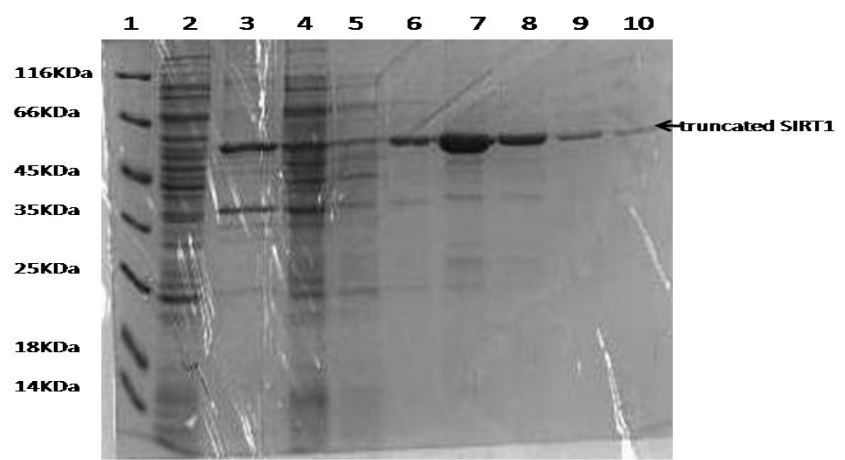

Fig. 3- Purification of human truncated SIRT1 by Ni-NTA column: Lane1: Molecular weight marker, Lane2-5:flow through and washings, Lane 6-10: refolded purified protein

\section{Western Blot}

Purified truncated SIRT1 which reacted with rabbit anti SIRT1 polyclonal antibody was apparent as a single band. To compare the full length and truncated protein we used human serum sample and found that the molecular weight of full length human SIRT1 was of around $81 \mathrm{KDa}$ while the truncated protein was of only $51 \mathrm{kDa}$ (Fig 4).

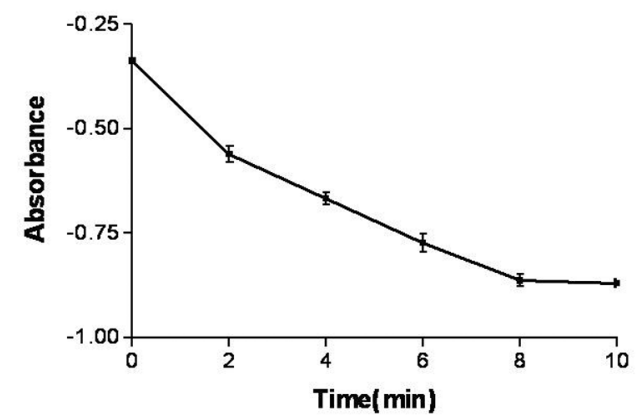

Fig. 4- Western blot showing the specificity of human truncated SIRT1 compared to SIRT1 present in human serum

\section{Truncated SIRT1 assessment by SPR.}

The SPR signal for immobilization of antibody of SIRT1 was found to be $14908.5 \mathrm{RU}$ where $1 \mathrm{RU}$ corresponds to immobilized protein concentration of $1 \mathrm{pg} / \mathrm{mm}^{2}$. Six different amounts of pure recombinant SIRT1 in HBS-EP buffer were passed over the immobilized SIRT1 anti body and the RU obtained were 14918.4, 15021.1, 15115.5, 15473.6, 15768.3 and $16982.0 \mathrm{RU}$. The curve was plotted with RU obtained from the sensogram with different concentrations of pure truncated SIRT1 as mentioned above. The binding of the ligands i.e. truncated SIRT1 were in the linear range shown in Fig 5. The RU increased linearly as the concentration of truncated SIRT1 increases.

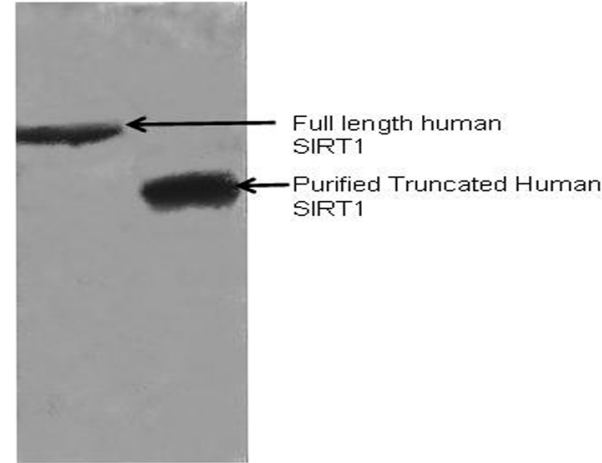

Fig. 5- RU values obtained by passing six different amounts $(0.62$ $\mathrm{ng}, 3.12 \mathrm{ng} 6.25 \mathrm{ng}, 18.75 \mathrm{ng}, 31.25 \mathrm{ng}$ and $62.25 \mathrm{ng}$ ) of truncated SIRT1 over immobilized antiSIRT1 antibody

\section{MASS Spectrometry}

The purified protein band was excised from gel and identified through Mass Spectrometry. The trypsanized fragments were analyzed through a mascot search program from matrix science shows candidate proteins as SIRT1 and a score of 116 based on probability analysis. The score of 116 for an MS/MS match in Mascot search depends upon the absolute probability that the selected match between reported data and the database sequence is a random event.

\section{Enzyme Activity}

The activity assay was performed as described by Smith et al in which the rate of nicotinamide formation was measured using a coupled enzyme system with nicotinamidase and glutamate dehydrogenase. Nicotinamidase hydrolyses nicotinamide to nicotinic acid and ammonia. Glutamate dehydrogenase then converts ammonia, a-ketoglutarate, and $\mathrm{NAD}(\mathrm{P}) \mathrm{H}$ to glutamate and $\mathrm{NAD}(\mathrm{P})^{+}$. $\mathrm{NAD}(\mathrm{P}) \mathrm{H}$ oxidation/consumption is measured spectrophotometrically at $340 \mathrm{~nm}$. A linear response was obtained from the coupled enzyme reaction (Fig 6). Through this assay it was established that the purified truncated protein possess histone deacetylase activity.

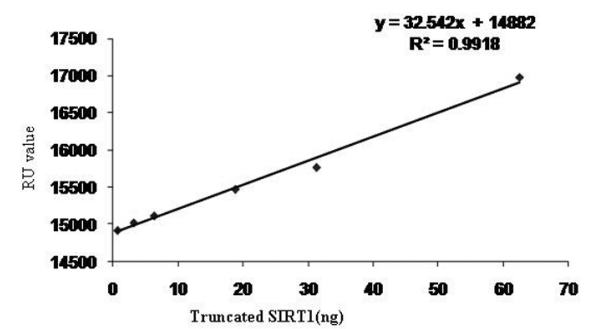

Fig. 6- Activity assay of human truncated SIRT1: Linear response due to the consumption of $\mathrm{NAD}(\mathrm{P}) \mathrm{H}$ with time.

\section{Discussion}

The first gene discovered in the Sirtuin family was Sir2 from yeast, is able to extend the life span in various organisms. Seven human homologous of sirtuins (SIRT1-7) which share the catalytic domain with Sir2 have been characterized [26, 27]. The anti ageing effects of human homologous of sirtuins are also seen by animal and human associated studies.SIRT1, the most studied of 7 sirtuin family members, is a key mediator of the pathways down- 
stream of calorie restriction, dietary regimen that is known to delay the onset of ageing and reduce the incidence of age related diseases. SIRT1 has been proved to be a potential therapeutic target for age associated diseases.

Since the catalytic domain of full length human sirtuin consist of 255 conserved amino acids (244-498 aa), we have cloned and expressed a protein from 193 to 611 amino acids residues to keep the activity intact in expressed protein. The primers were designed based on the sequence of human SIRT1 mRNA sequence which was obtained from NCBI (NM_012238) of $4110 \mathrm{bp}$. The cloned gene includes an ORF of 1260 bp encoding 420 amino acids residues.

The protein was characterized by mass spectroscopy, SDS PAGE and Western Blot was found to be of $51 \mathrm{kDa}$ and pl value of 5.1 . The specificity of protein was identified by using its specific antibody by western blotting and SPR. In SPR the sensogram increases linearly as the mass of the SIRT1 increases over the antibody.

This sequence shows high similarity with other species' SIRT1. The amino acid sequence of truncated SIRT1 sequence shared 99\% identity to SIRT1FL_human, $97 \%$ identity to Sus scrofa, $94 \%$ identity to Bos taurus, $93 \%$ to Cricetulus griseus, $93 \%$ to Mus musculus, $94 \%$ to Oryctolagus cuniculus, $92 \%$ to Callithrix jacchus, $91 \%$ to Ailuropoda melanoleuc, $93 \%$ to Mustela putorius furo, $51 \%$ to Drosophila melanogaster and $41 \%$ to Caenorhabditis elegans (Table 1). The Fig. 7 shows the high homology of truncated SIRT1 with the conserved catalytic domain of other mammalian SIRT1.
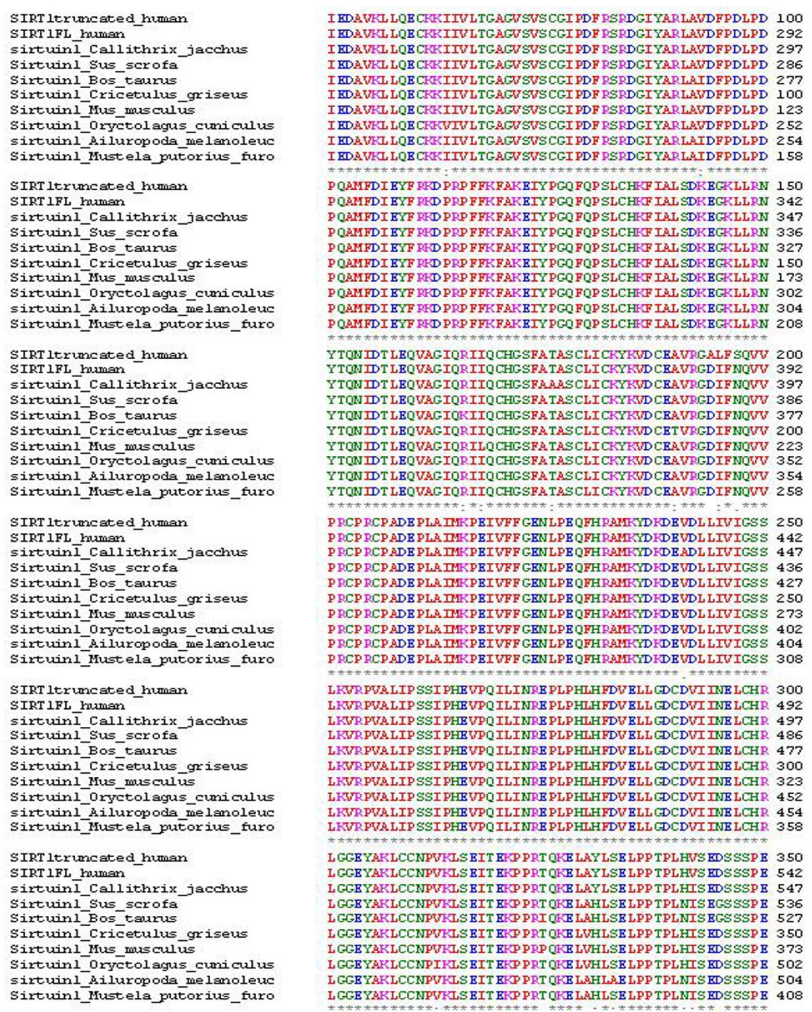

Fig. 7- The sequence alignment of catalytic domain of human truncated SIRT1 with other mammalian SIRT1
Table1- The sequence similarity of human truncated SIRT1 with sirtuin of other species

\begin{tabular}{|lll|}
\hline Species name & Gen bank accession no. & Percentage identity \\
\hline Homo sapiens & NP_036370.2 & 99 \\
Callithrix jacchus & XP_002756358.1 & 92 \\
Sus scrofa & NP_001139222.1 & 97 \\
Bos taurus & NP_001179909.1 & 94 \\
Cricetulus griseus & EGW03730.1 & 93 \\
Mus musculus & AAI52315.1 & 93 \\
Oryctolagus cuniculus & XP_002718507.1 & 94 \\
Ailuropoda melanoleuc & XP_002913805.1 & 91 \\
Mustela putorius furo & AES06615.1 & 93 \\
Drosophila melanogaster & NP_477351 & 51 \\
Caenorhabditis elegans. & CBK19468.1 & 41 \\
\hline
\end{tabular}

The enzymes that produce the nicotinamide from the catabolism of $\mathrm{NAD}^{+}$are the mediator of many physiological processes [28]. Sirtuin protein used $\mathrm{NAD}^{+}$as a co-substrate during catalysis for deacetylation to remove the acetyl group from the acetyl lysine residues of protein forming deacetylated protein, 0-acetyl-ADPribose and nicotinamide. Sirtuin use NAD+ to form one molecule of nicotinamide for every lysine residue deacetylated. The cloned truncated SIRT1protein in the present study binds with both substrates $\mathrm{AcH} 3$ and cosubstrate $\mathrm{NAD}^{+}$to produce nicotinamide.

\section{Conclusion}

It can be concluded that the truncated sirtuin 1 of 420 amino acids which is homologous to full length SIRT1 can be easily expressed in $E$. coli. The protein is purified and refolded in active form and binds to both substrate and co substrate to deacetylate the acetylated protein. It can be used for the in vitro study for the development of new therapeutic agent.

\section{Acknowledgements}

Authors acknowledge School of Life Science, Jawaharlal Nehru University for performing MASS analysis of truncated protein SIRT1and thankful to Dr. Daisuke Koya and Dr.Jorge C. Escalante-Semerena for providing cDNA of SIRT1 and pPnc2 respectively.

Authors acknowledge Council of Scientific and Industrial Research for the fellowship of Rahul Kumar.

\section{References}

[1] Avalos J.L., Bever K.M. and Wolberger C. (2005) Mol. Cell., 17(6), 855-868.

[2] Hoff K.G., Avalos J.L., Sens K. and Wolberger C. (2006) Structure, 14(8), 1231-1240.

[3] Huhtiniemi T., Wittekindt C., Laitinen T., Leppanen J., Salminen A., Poso A. and LahtelaKakkonen M. (2006) J. Comput. Aided Mol. Des., 20(9), 589-599.

[4] Kaeberlein M., McVey M. and Guarente L. (1999) Genes. Dev., 13(19), 2570-2580.

[5] Tissenbaum H.A. and Guarente L. (2001) Nature, 410(6825), 227-230.

[6] Rogina B. and Helfand S.L. (2004) Proc. Natl. Acad. Sci. USA, 101(45), 15998-16003.

[7] Wood J.G., Rogina B., Lavu S., Howitz K., Helfand S.L., Tatar M. and Sinclair D. (2004) Nature, 430(7000), 686-689.

[8] Sinclair D.A., Lin S.J. and Guarente L. (2006) Science, 312 
(5771), 195-197.

[9] Colman R.J., Anderson R.M., Johnson S.C., Kastman E.K., Kosmatka K.J., Beasley T.M., Allison D.B., Cruzen C., Simmons H.A., Kemnitz J.W. and Weindruch R. (2009) Science, 325(5937), 201-204.

[10]Luo J., Nikolaev A.Y., Imai S., Chen D., Su F., Shiloh A., Guarente L. and Gu W. (2001) Cell., 107(2), 137-148.

[11]Vaziri H., Dessain S.K., Eaton E., Imai S.I., Frye R.A., Pandita T.K., Guarente L. and Weinberg R.A. (2001) Cell., 107(2), 149 $-159$.

[12]Haigis M.C. and Guarente L.P. (2006) Genes. Dev., 20(21), 2913-2921.

[13]Motta M.C., Divecha N., Lemieux M., Kamel C., Chen D., Gu W., Bultsma Y., McBurney M. and Guarente L. (2004) Cell., 116(4), 551-563.

[14]Bereshchenko O.R., Gu W. and Dalla-Favera R. (2002) Nat. Genet., 32(4), 606-613.

[15]Muth V., Nadaud S., Grummt I. and Voit R. (2001) Embo. J., 20(6), 1353-1362.

[16]Takata T. and Ishikawa F. (2003) Biochem. Biophys. Res. Commun., 301(1), 250-257.

[17]Senawong T., Peterson V.J., Avram D., Shepherd D.M., Frye R.A., Minucci S. and Leid M. (2003) J. Biol. Chem., 278(44), 43041-43050.

[18]Liang F., Kume S. and Koya D. (2009) Nat. Rev. Endocrinol., $5(7), 367-373$

[19]Picard F., Kurtev M., Chung N., Topark-Ngarm A., Senawong T., Machado De Oliveira R., Leid M., McBurney M.W. and Guarente L. (2004) Nature, 429(6993), 771-776.

[20]Lagouge M., Argmann C., Gerhart-Hines Z., Meziane H., Lerin C., Daussin F., Messadeq N., Milne J., Lambert P., Elliott P., Geny B., Laakso M., Puigserver P. and Auwerx J. (2006) Cell., 127(6), 1109-1122.

[21]Gerhart-Hines Z., Rodgers J.T., Bare O., Lerin C., Kim S.H., Mostoslavsky R., Alt F.W., Wu Z. and Puigserver P. (2007) Embo. J., 26(7), 1913-1923.

[22]Rodgers J.T., Lerin C., Haas W., Gygi S.P., Spiegelman B.M. and Puigserver P. (2005) Nature, 434(7029), 113-118.

[23]Holbourn K.P., Lloyd M.D., Thompson A.S., Threadgill M.D. and Acharya K.R. Acta Crystallogr Sect F Struct Biol Cryst Commun, 67(Pt 4), 461-463.

[24]Garrity J., Gardner J.G., Hawse W., Wolberger C. and Escalante-Semerena J.C. (2007) J. Biol. Chem., 282(41), 30239-30245.

[25]Smith B.C., Hallows W.C. and Denu J.M. (2009) Anal Biochem., 394(1), 101-109.

[26]Afshar G. and Murnane J.P. (1999) Gene., 234(1), 161-168.

[27]Frye R.A. (2000) Biochem. Biophys. Res. Commun., 273(2), 793-798.

[28]Schreiber V., Dantzer F., Ame J.C. and de Murcia G. (2006) Nat. Rev. Mol. Cell. Biol., 7(7), 517-528. 